\title{
Plenary Lecture
}

\section{Protein nutrition of the neonate}

\author{
Peter J. Reeds*, Douglas G. Burrin, Teresa A. Davis, Marta L. Fiorotto, Barbara Stoll and \\ Johannes B. van Goudoever \\ USDA/ARS Children's Nutrition Research Center, Department of Pediatrics, Baylor College of Medicine, Houston, \\ TX 77030, USA
}

\begin{abstract}
The period of growth and development between birth and weaning is crucial for the long-term well-being of the organism. Protein deposition is very rapid, is achieved with a high nutritional efficiency, and is accompanied by marked differences in the growth rates of individual tissues and a series of maturational processes. These important aspects of development occur while the neonate is consuming a single and highly-specific food source, milk. Surprisingly, although there is a clear relationship between the nutrient density of milk and the growth rate of its recipient, this relationship does not apply to the overall amino acid composition of mixed milk proteins. Some amino acids, notably glycine and arginine, are supplied in milk in quantities that are much less than the needs of the neonate. The milk-fed neonate is therefore capable of carrying out a tightlyregulated transfer of $\mathrm{N}$ from amino acids in excess to those that are deficient. The rapid growth of the neonate is supported by a high rate of tissue protein synthesis. This process appears to be activated by the consumption of the first meals of colostrum. Recent research has identified that skeletal muscle and the brain are specifically responsive to an unidentified factor in colostrum. Following the initial anabolic response the rate of protein synthesis in some tissues, notably muscle, falls from birth to weaning. This decrease reflects a progressively smaller anabolic response to nutrient intake, which not only involves an overall fall in the capacity for protein synthesis, but also in responses to insulin and amino acids. The study of growth and protein metabolism, and their regulation in the neonate is not only important for pediatrics, but may provide important pointers to more general aspects of regulation that could be applied to the nutrition of the mature animal.
\end{abstract}

Neonate: Milk composition: Amino acid: Protein synthesis: Insulin

In some senses, the sucking period can be regarded as a transition from the protected existence of the fetus to the vulnerable life of the free-living organism. At birth the route of nutrition shifts from parenteral to enteral, necessitating among other things a rapid rate of postnatal intestinal development, and the diet that the newborn receives is of relatively (although not completely) constant composition. At weaning the nature of the diet changes to one that is variable in physical form, nutrient composition and amount. The combination of these factors necessitates the development of functions that allow the organism to adapt and accommodate to the uncontrolled changes in diet availability and composition that inevitably follow weaning.
Indeed, it could be argued that much of the functional maturation that occurs over the sucking period is a preparation for the independent life of the weaned individual. In the present paper we will consider three main aspects of the protein nutrition of the neonate. First, we will discuss amino acid requirements from a factorial and compositional perspective, and examine the degree to which predicted requirements are satisfied by milk. Second, we will consider some of the intermediary metabolic implications of the differences between the composition of mixed body and milk proteins. Finally, we will consider more dynamic aspects of protein metabolism and discuss recent work on nutritional and endocrine factors that 
regulate protein turnover, factors that potentially influence the efficiency with which the neonate utilizes its dietary protein.

\section{Protein deposition, milk composition and amino acid needs}

Irrespective of the stage of development, the quantification of the dietary protein and amino acid requirements of any organism demands three items of information. First, quantitative data on the rates of the pathways that consume individual amino acids, which defines the basal biological need. Second, information on the bioavailability of the amino acids from a given protein source, which defines the efficiency with which a given diet satisfies the biological needs. Third, estimates of the inter-individual variability in, and environmental influences on, amino acid needs. These factors influence the efficiency with which a given individual is able to utilize available amino acids and, we would argue, are critical pieces of information if requirements, as defined by the first two factors, are to be converted into practical dietary recommendations.

The processes that utilize amino acids can be loosely placed into two categories, protein deposition and the so-called maintenance pathways of amino acid utilization. Largely because of limitations of space, we will not consider in detail the biological basis of maintenance amino acid needs. Nonetheless, it should be emphasized that this aspect of amino acid nutrition is of specific quantitative importance to the human subject. Furthermore, a strong case can be made in favour of the idea that pathways of amino acid utilization, associated with tissue function and immune protection rather than with protein turnover, are critical to this aspect of amino acid nutrition. Discussions of this subject can be found in Dewey et al. (1996) and Reeds \& Beckett (1996).

In principle it is possible to quantify the amino acid needs for protein deposition simply from the product of its rate and amino acid composition. For older animals the estimate of amino acid requirement calculated in this way is very similar to that defined from $\mathrm{N}$ balance trials (Fuller et al. 1989). However, one important characteristic of growth in the early postpartum period is the markedly different rates of growth among the tissues, with intestinal growth being particularly rapid (Fig. 1). Since the proteins deposited at each site differ in amino acid composition (Table 1), it is possible that the relative need for each amino acid will vary over the sucking period. In rats (Davis et al. 1993) and pigs (Mahan \& Shields, 1998) there are some differences in the amino acid composition of protein gain from birth to weaning, which seem to be largely a function of the varying contribution of collagen to whole-body protein. However, these differences are quite small, an observation that probably reflects the dominating influence of skeletal muscle protein deposition on whole-body amino acid accretion.

From a strictly dietetic perspective the hallmark of the sucking period is the consumption of a highly-specific diet (milk) of relatively, although not absolutely, constant composition. As one might hypothesize that milk and its recipients have co-evolved, it might be predicted that the

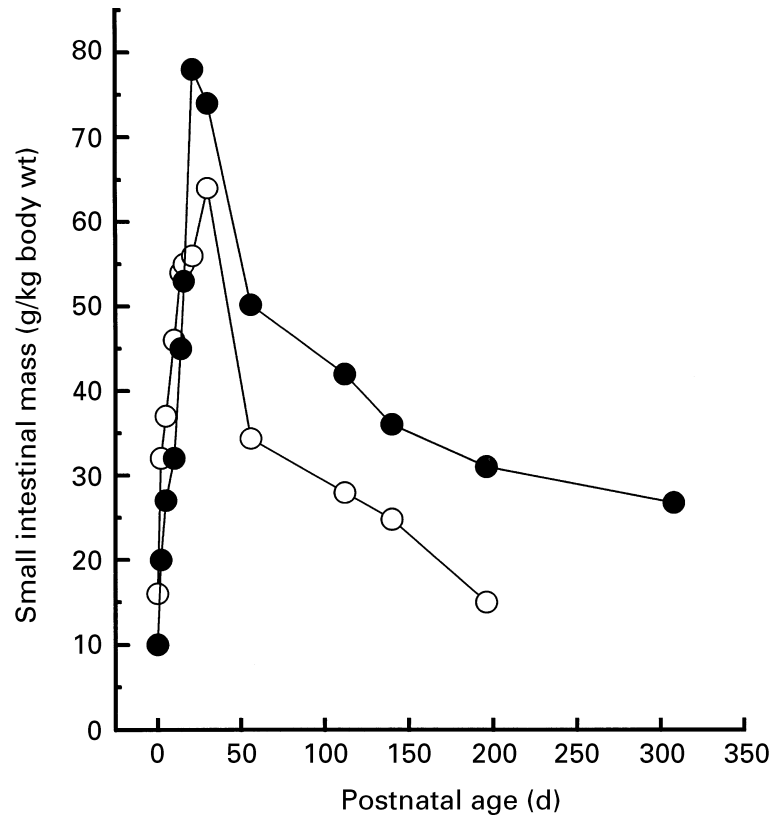

Fig. 1. Relationship between postnatal age and small intestinal mass in rats and pigs. (•), Rat data taken from Goldspink et al. (1984) and Burrin et al. (1991); (o), pig data from McMeekan (1940) and DG Burrin, $R$ Jiang and B Stoll, unpublished results.

Table 1. Amino acid composition ( $\mathrm{mg}$ amino acid/g protein) of the mixed proteins of different porcine tissues

\begin{tabular}{|c|c|c|c|c|}
\hline \multirow[b]{2}{*}{ Amino acid } & \multicolumn{4}{|c|}{ Tissue* } \\
\hline & $\begin{array}{l}\text { Skeletal } \\
\text { muscle }\end{array}$ & Liver & $\begin{array}{l}\text { Intestinal } \\
\text { mucosa }\end{array}$ & Skin \\
\hline Glycine & 48 & 76 & 94 & 195 \\
\hline Arginine & 63 & 58 & 57 & 79 \\
\hline Alanine & 59 & 71 & 78 & 95 \\
\hline Threonine & 46 & 46 & 54 & 30 \\
\hline Aspartate $†$ & 94 & 87 & 92 & 73 \\
\hline Valine & 55 & 63 & 58 & 40 \\
\hline Phenylalanine & 41 & 45 & 42 & 32 \\
\hline Lysine & 92 & 74 & 70 & 45 \\
\hline Histidine & 41 & 23 & 16 & 12 \\
\hline Tryptophan & 12 & 14 & ND & 2 \\
\hline Leucine & 82 & 79 & 94 & 54 \\
\hline Methionine & 27 & 25 & 17 & 8 \\
\hline Cysteine & 13 & 19 & ND & 10 \\
\hline Isoleucine & 48 & 49 & 45 & 23 \\
\hline Serine & 42 & 55 & 58 & 42 \\
\hline Proline & 41 & 55 & 54 & 119 \\
\hline Tyrosine & 35 & 29 & 36 & 20 \\
\hline Glutamate† & 159 & 122 & 120 & 124 \\
\hline
\end{tabular}

*Data for skeletal muscle and skin were calculated from US Department of Agriculture nutrient composition data accessed via www.nal.usda.gov/ fnic/foodcomp

Values for liver and intestinal mucosa are from B Stoll, DG Burrin and PJ Reeds, unpublished results.

†The sum of asparagine and aspartates, and glutamine and glutamate.

composition of a given species' milk would reflect the peculiar nutritional and developmental needs of the neonate of that species. In a qualitative sense, the idea of co-evolution is supported by observations that milks of 
different species contain different panels of growth factors and hormones (Klagsbrun, 1978; Francis et al. 1988; Odle et al. 1996; Burrin et al. 1997b) and that milk contains quite high concentrations of endproducts of other metabolic pathways. These endproducts include complex oligosaccharides (Newburg, 1997), nucleotides (Uauy et al. 1994) and other endproducts of amino acid metabolism (Table 2). Moreover, there is a linear relationship between the nutrient density (exemplified by the protein density in Fig. 2) of a given species' milk and the growth rate of the suckling. The protein concentration of milk and the weightspecific rate of protein deposition also tend to parallel one another as the period of lactation progresses (for example, see Fiorottto et al. 1991; Dewey et al. 1996; Dourmad et al. 1998).

Since different species exhibit markedly different weightspecific postnatal growth rates (Fig. 2), and because maintenance amino acid requirements are a function of body weight, there are quite marked differences in the relative contributions of protein deposition and $\mathrm{N}$ maintenance to total amino acid requirements among different species. For example, even though the body protein mass of the sucking rat increases by an order of magnitude over the first 3 weeks of life, during this period the maintenance protein

Table 2. Non-protein nitrogenous components of human milk

\begin{tabular}{lccl}
\hline & \multicolumn{2}{c}{ Concentration $(\mu \mathrm{mol} / \mathrm{l})$} & \\
\cline { 2 - 3 } Component & Mean & SD & Reference \\
\hline Glutamine & 580 & 46 & Rassin et al. (1978) \\
Taurine & 410 & 70 & Rassin et al. (1978) \\
Creatine & 140 & 17 & Macy (1949) \\
Polyamines & 8 & 2 & Romain et al. (1992) \\
Nucleotides & 69 & 12 & Sugawara et al. (1995) \\
GSH & 300 & 56 & J Henry and PJ Reeds \\
& & & (unpublished results) \\
\hline
\end{tabular}

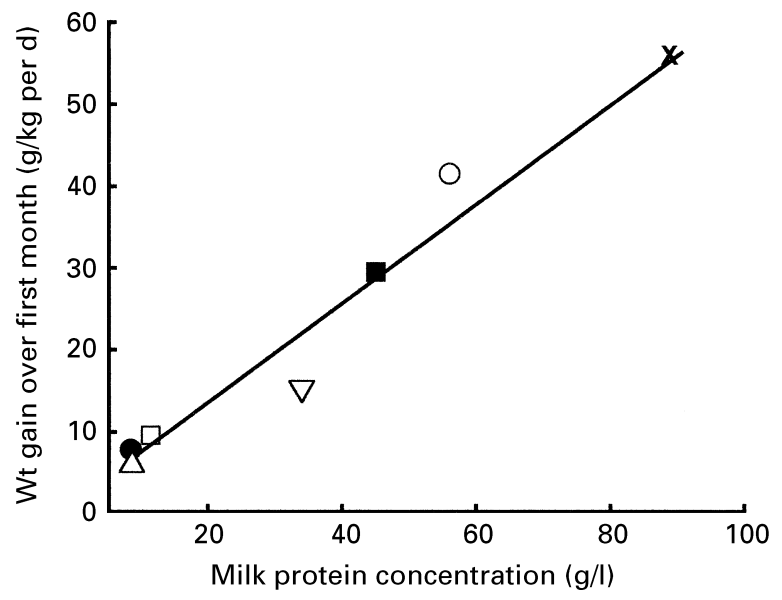

Fig. 2. Milk protein and postnatal weight gain in different coronal species. Milk protein concentration taken from Davis et al. (1994). Animal growth data: (•), man (Dewey et al. 1996); $(\Delta),(\square)$, chimpanzee and gorilla respectively (Smith \& Leigh, 1998; S Leigh, personal communication); ( $\nabla)$, cattle (Anderson et al. 1999); (घ), sheep (Greenwood et al. 1998); (X) rat (Fiorotto et al. 1991); (০), pig. requirement is less than $5 \%$ of the total. In contrast, even during the first month of postnatal growth $35 \%$ of the protein requirement of the human infant is associated with the maintenance of body $\mathrm{N}$ equilibrium. In growing animals, the relative amino acid requirements for growth and maintenance of $\mathrm{N}$ equilibrium appear to be markedly different (Fuller et al. 1989). It might be expected, therefore, that there would be parallels between the amino acid composition of a given milk and rate of protein deposition of the neonate. However, while an extensive survey of the amino acid composition of different mammalian milks (Davis et al. 1993, 1994, 1995) revealed some interesting interspecific differences in the concentrations of individual amino acids (e.g. the high tryptophan content of human milk, the high arginine content of felid milk and the high cysteine and serine content of rat milk) there appears to be no systematic relationship between the rate of growth of the neonate of a given species and the amino acid composition of the mixed milk proteins that it receives.

On the other hand, when data for milk amino acid composition are compared with the amino acid composition of mixed body protein (Fig. 3), observations of potential biological importance emerge. First, across species, threonine appears to be the first limiting essential amino acid for the protein accretion of the sucking neonate. Other essential amino acids are provided in milk at rates that either closely match (valine, phenylalanine, lysine and histidine) or exceed their utilization for protein deposition (e.g. leucine, methionine and isoleucine). In this sense milk is a relatively efficient vehicle for the delivery of essential amino acids for protein deposition. However, in other respects the amino acid mixture of milk is imbalanced. Irrespective of the species glutamate + glutamine contribute $20 \%$ of total milk amino acids, and $40 \%$ of the total amino

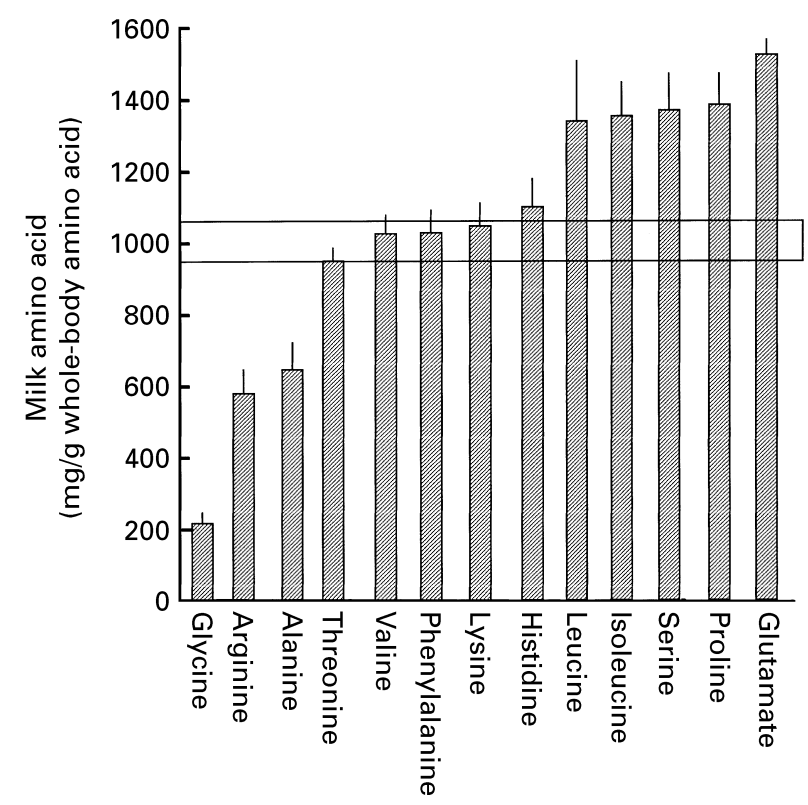

Fig. 3. Relationship between the amino acid composition of the milk and mixed body protein of six mammalian species. Data for the composition of human, gorilla, cattle, sheep, pig and rat milk were obtained from Davis et al. (1993, 1994). Values are means and 1 SD represented by vertical bars. 
acid intake of the milk-fed neonate is accounted for by glutamate+glutamine, proline and leucine. On the other hand, arginine, alanine and particularly glycine are remarkably deficient in milk.

\section{Amino acid metabolism in the neonate}

The presence of substantial excesses (e.g. glutamate, glutamine, leucine and isoleucine) and deficiencies (arginine, alanine and glycine) of specific amino acids in mixed milk proteins has some interesting implications. First, in order to deposit protein at a high rate, the milk-fed neonate has to carry out the regulated transfer of $\mathrm{N}$ from amino acids that are in substantial excess to those that are deficient. Thus, while the efficiency of utilization of individual amino acids for protein deposition varies in proportion to the degree to which their intake satisfies the need for protein deposition, the naturally-fed sucking mammal exhibits a high efficiency of utilization of milk protein-N for protein deposition (Table 3). Interestingly, when an estimate of maintenance $\mathrm{N}$ needs (approximately $100 \mathrm{mg} \mathrm{N} / \mathrm{kg}$ body weight; see Dewey et al. 1996) is included in the calculation, then the incremental efficiency with which milk amino acids are deposited in body protein is not only very high, but also similar across the species considered in Table 3 .

Table 3. The efficiency of utilization of milk total nitrogen during the first month of postnatal life ${ }^{\star}$

\begin{tabular}{|c|c|c|c|c|c|}
\hline \multirow[b]{2}{*}{ Species } & \multicolumn{3}{|c|}{$\mathrm{N}$ for whole period $(\mathrm{g})$} & \multicolumn{2}{|c|}{$\begin{array}{l}\text { Efficiency of utilization } \\
\text { (\% intake) }\end{array}$} \\
\hline & $\begin{array}{c}\text { Total } \\
\text { intake }\end{array}$ & $\begin{array}{c}\text { Total } \\
\text { deposited }\end{array}$ & $\begin{array}{l}\text { Mainte- } \\
\text { nance }\end{array}$ & Grosst & Netł \\
\hline Rat & $1 \cdot 25$ & 0.98 & 0.06 & 78 & 82 \\
\hline Man & $27 \cdot 4$ & $15 \cdot 5$ & $9 \cdot 7$ & 56 & 87 \\
\hline Pig & 185 & 136 & 18 & 74 & 81 \\
\hline Sheep & 290 & 197 & 28 & 68 & 78 \\
\hline
\end{tabular}

*Data are normalized to a litter of ten for rats and pigs, and ovine and human data are for single offspring. Milk output is from Davis et al. (1993) for rats, Dourmad et al. (1998) for pigs, AW Bell (personal communication) for sheep and Dewey et al. (1996) for human subjects. Body protein gain (normalized to $30 \mathrm{~d}$ ) is from Fiorotto et al. (1991) and Davis et al. (1994) for rats, Mahan \&

Shields (1998) and Wu et al. (1999) for pigs, Greenwood et al. (1998) for sheep and Dewey et al. (1996) for human infants. It was assumed that maintenance $\mathrm{N}$ intake was $100 \mathrm{mg} \mathrm{N} / \mathrm{kg}$ body weight per $\mathrm{d}$.

†Percentage of total protein intake deposited.

$\ddagger$ Percentage of protein intake above maintenance that was deposited.
A direct illustration of the ability of the neonate to 'balance' the $\mathrm{N}$ among amino acids is provided by the experiments of TA Davis (unpublished results). In these studies (Table 4) 7-d-old piglets were infused with insulin at a rate that achieved an insulin concentration similar to that found in the fed state, glucose and essential amino acid concentrations were maintained at their fasting values, and leucine turnover and oxidation were measured with continuous intravenous infusions of $\left[1-{ }^{13} \mathrm{C}\right]$ leucine. In separate experiments the amino acid mixture used to maintain amino acid concentrations was either a conventional paediatric parenteral nutrition solution, which contains relatively low amounts of non-essential amino acids, or a solution that had been supplemented with glutamine, glutamate, glycine and alanine. During the infusion of the imbalanced amino acid mixture plasma urea concentrations did not change, so that all the infused amino acid-N was utilized for anabolism. Nevertheless, leucine-C catabolism was increased 2.4-fold by insulin infusion, critically under conditions in which the plasma leucine concentration had not changed. In other words, leucine-N must have been transferred to those non-essential amino acids that were infused in low amounts. However, during the infusion of insulin together with the supplemented amino acid mixture leucine catabolism increased by only 1.5 -fold, less leucine had to be infused to maintain leucine concentrations at their fasting value and a higher proportion of the additional leucine was stored. These results suggest that the neonate possesses mechanisms that allow it to sense an imbalance in the amino acid supply, and not only allow it to mount acute changes in the metabolism of specific amino acids, but to do so via a mechanism that is independent of changes in the circulating concentration of the amino acid in question. The nature of the mechanism remains unknown. It clearly allows the neonate to utilize its total amino acid intake with a high degree of efficiency. These observations have broader implications for the regulation of amino acid metabolism at other stages of development and merit closer attention.

The experiment described earlier was carried out under artificial circumstances, in as much as the amino acids were administered intravenously. Of course, under natural conditions the interconversion of amino acids must be achieved from the enteral amino acid input. In fact, we would go further, and argue that metabolism in the small intestine is critically important to this N-balancing

Table 4. Leucine utilization in 7-d-old piglets receiving intravenous infusions of insulin and glucose, with the circulating concentrations of essential amino acids (EAA) being maintained at fasting values with the infusion of isonitrogenous mixtures of amino acids containing different proportions of non-essential amino acids (NEAA) and EAA. Data from TA Davis, PR Beckett, ML Fiorotto, H Nguyen and DG Burrin (unpublished results)*

\begin{tabular}{lcccc}
\hline & \multicolumn{3}{c}{ Leucine kinetics $(\mu \mathrm{mol} / \mathrm{kg} \mathrm{per} \mathrm{h})$} & \\
\cline { 2 - 4 } Condition & Infused & Oxidized & Balance & Storage of infused leucine $(\%$ infused $)$ \\
\hline Fasting & 0 & 196 & -196 & NA \\
Low NEAA : EAA & 366 & 488 & -122 & 20 \\
Balanced NEAA : EAA & 241 & 309 & -69 & 53 \\
Pooled SD & 66 & 87 & 65 & 8 \\
Effect of amino acid mixture & $P<0.01$ & $P<0.01$ & $\mathrm{NS}$ & $P<0.01$
\end{tabular}

*It is critical to note that the circulating leucine concentration was the same during all three infusions. 
phenomenon. In the context of the milk-fed neonate it is critical to note that glutamine (Windmueller \& Spaeth, 1980) and glutamate (Stoll et al. 1999; Table 5) appear to be crucial energy substrates for the intestinal mucosa. In view of this factor, and the demonstrated ability of the intestine of piglets and infants to use considerable quantities of dietary glutamate and glutamine (Reeds et al. 1996; Darmaun et al. 1997), it seems reasonable to come to the teleological conclusion that the high concentration of glutamate (+glutamine) in milk may have evolved specifically to support the metabolism of the mucosa. Furthermore, the high rate of utilization of dietary glutamate by the intestinal tissues implies that virtually all the systemic glutamate (and probably glutamine) derives from endogenous synthesis. This factor, as we have shown, has consequences for the utilization of leucine (see Table 4) and isoleucine, two amino acids that are not only important $\mathrm{N}$ donors for glutamate and glutamine synthesis but are in excess in milk.

The high concentrations of glutamate and glutamine in milk also have a bearing on the arginine and alanine status of the milk-fed neonate. It has been known for many years that the intestinal mucosa is capable of synthesizing alanine from dietary glutamate (Neame \& Wiseman, 1957; Windmueller \& Spaeth, 1980), and we have confirmed the presence of this process in the piglet (Stoll et al. 1999). Furthermore, the intestine is such a critical site for citrulline synthesis (Windmueller \& Spaeth, 1980), that arginine, which is synthesized from this citrulline, becomes an essential amino acid following massive gut resection (Wakabayashi et al. 1995), as well as in parenterallynourished individuals (Motil et al. 1980). Recent work suggests, moreover, that the intestinal mucosa of the newborn is capable of the complete synthesis of arginine (Blachier et al. 1993; Wu \& Knabe, 1995; Stoll et al. 1999), and that inhibition of ornithine transaminase, a key enzyme in mucosal arginine synthesis, substantially compromises circulating arginine concentrations in the neonatal piglet (Wu et al. 1997). Thus, the high concentrations of milk glutamate and glutamine not only support the metabolic needs of a crucially important tissue, but glutamate metabolism in the gut makes the dominant contribution to the synthesis of two of the amino acids that are in short supply in milk.

In many respects the most remarkable feature of the amino acid composition of milk is the substantial glycine deficit. Indeed, both on the basis of simple mass balance calculations and on the basis of the results of studies of

Table 5. The contribution of dietary and systemic substrates to energy generation in the portal-drained viscera of 4-week-old milk-fed piglets (Data from Stoll et al. 1999)

(Values are means and $1 \mathrm{SD}$ )

\begin{tabular}{lccccc}
\hline & $\begin{array}{c}\text { Percentage of } \\
\text { uptake oxidized }\end{array}$ & & \multicolumn{2}{c}{$\begin{array}{c}\text { Contribution to visceral } \\
\mathrm{CO}_{2} \text { production (\%) }\end{array}$} \\
\cline { 2 - 3 } \cline { 5 - 6 } Substrate & Mean & 1 SD & & Mean & $1 \mathrm{SD}$ \\
\hline Dietary glucose & 2 & 1 & & 6 & 2 \\
$\begin{array}{l}\text { Dietary } \\
\text { glutamate }\end{array}$ & 52 & 3 & & 36 & 3 \\
Arterial glucose & 27 & 9 & & 29 & 3 \\
Arterial glutamine & 70 & 8 & & 15 & 2 \\
\hline
\end{tabular}

glycine-N metabolism in infants (Jackson et al. 1981), it can be concluded that glycine is a specific limitation to the growth of the normal neonate. The dietary glycine deficit is even more notable because glycine is a precursor for a number of nutritionally-significant metabolic pathways that are functionally, but not directly, related to protein deposition. Thus, glycine is an obligatory precursor for purine base synthesis. This factor is important because recent data have suggested that mammalian nucleic acid synthesis relies on intracellular purine synthesis de novo (Berthold et al. 1995; Boza et al. 1996; Perez \& Reeds, 1998). Glycine is also a precursor for the synthesis of creatine, a factor that is crucial for the maintenance of energy flow both in skeletal muscle and the central nervous system. Finally, glycine is also a component amino acid of $\mathrm{GSH}$, a tripeptide that is a critical factor in the maintenance of peroxidative defences and cellular integrity, and is also the $\mathrm{N}$ source of haem. Thus, the true requirement for glycine is in excess of that consumed in protein deposition, and the synthesis of glycine in the milk-fed neonate, irrespective of species, must be very high.

Surprisingly, despite the critical importance of glycine synthesis to a number of aspects of the function of the neonate, and even though we know on the basis of measurements of the glycine flux that glycine must be synthesized, the pathway that is utilized remains obscure. On the basis of the literature, two pathways might be utilized.

The first is the synthesis of glycine from serine. However, it is important to note that the quantities of serine in milk are insufficient to support even the minimum estimate of glycine synthesis necessary to explain glycine deposition during the period. Thus, serine synthesis, presumably from pyruvate, could be of high nutritional importance to the neonate (Miller et al. 1996). The other pathway of glycine synthesis is via the transamination of glyoxylate with alanine. The necessary peroxisomal enzyme has been identified in the liver of newborn rats (Snell \& Walker, 1974), but the precursor for glyoxylate synthesis is unknown. Hopefully, given the renewed interest in single $\mathrm{C}$ metabolism associated with the revitalization of folate research, more information on pathways of glycine synthesis will emerge.

\section{Feeding, protein turnover and growth}

The high rate of protein deposition of the neonate is, as one might expect, associated with a high rate of whole-body protein synthesis (Table 6), and this rate falls logarithmically from birth to the attainment of sexual maturity. However, the changes in whole-body protein synthesis that occur over the sucking period obscure a number of critical observations with regard to tissue protein synthesis and growth. First, in rats, pigs and sheep (and presumably in other species) there is a rapid activation of tissue protein synthesis during the first day of postnatal life (Fig. 4; see also Patureau-Mirand et al. 1990). At this time the natural food of the neonate is colostrum, a mammary secretion that has a higher nutrient density than mature milk. Thus, it is reasonable to ascribe a significant proportion of the increased protein synthesis to a response to nutrient intake itself. However, colostrum also contains particularly high 
Table 6. The relationship between age and whole-body protein synthesis (PS; $\mathrm{g} / \mathrm{kg}$ per d) in the fed state in various mammalian species (Values are means with 1SE)

\begin{tabular}{|c|c|c|c|c|c|c|c|c|c|c|c|}
\hline \multicolumn{3}{|c|}{ Rat $^{*}$} & \multicolumn{3}{|c|}{ Pigt } & \multicolumn{3}{|c|}{ Sheep $\ddagger$} & \multicolumn{3}{|c|}{ Man§ } \\
\hline \multirow[b]{2}{*}{ Stage } & \multicolumn{2}{|c|}{ PS } & \multirow[b]{2}{*}{ Stage } & \multicolumn{2}{|c|}{ PS } & \multirow[b]{2}{*}{ Stage } & \multicolumn{2}{|c|}{ PS } & \multirow[b]{2}{*}{ Stage } & \multicolumn{2}{|c|}{ PS } \\
\hline & Mean & $1 \mathrm{SE}$ & & Mean & $1 \mathrm{SE}$ & & Mean & $1 \mathrm{SE}$ & & Mean & $1 \mathrm{SE}$ \\
\hline $20 \mathrm{~d}$ fetus & 45 & 4 & $2.5 \mathrm{~kg}$ & 31 & 1 & $4.5 \mathrm{~kg}$ & 32 & 1 & Preterm & 11 & 2 \\
\hline $21 \mathrm{~d}$ old & 34 & 1 & $7 \cdot 5 \mathrm{~kg}$ & 24 & 7 & $25 \mathrm{~kg}$ & 8 & 1 & Term & 8 & 1 \\
\hline $56 \mathrm{~d}$ old & 20 & 1 & $30 \mathrm{~kg}$ & 18 & 4 & $45 \mathrm{~kg}$ & 5 & 1 & 18 months old $\|$ & 6 & 1 \\
\hline
\end{tabular}

*Goldspink \& Kelly (1984).

† Reeds et al. (1980); TA Davis, ML Fiorotto and DG Burrin (unpublished results); JB van Goudoever and B Stoll (unpublished results).

$\ddagger$ Pell et al. (1986); MacRae et al. (1988); Attaix et al. (1988); Harris et al. (1992).

$\S$ de Benoist et al. (1984); Denne et al. (1991, 1992, 1994, 1995); Kandil et al. (1991); Beaufrere et al. (1992); van Goudoever et al. (1995).

$\|$ The 18-month-old children had recovered from malnutriton and were studied with [ $\left.{ }^{15} \mathrm{~N}\right] \mathrm{glycine}$. Adult data are a summation of the literature on leucine flux measurements.

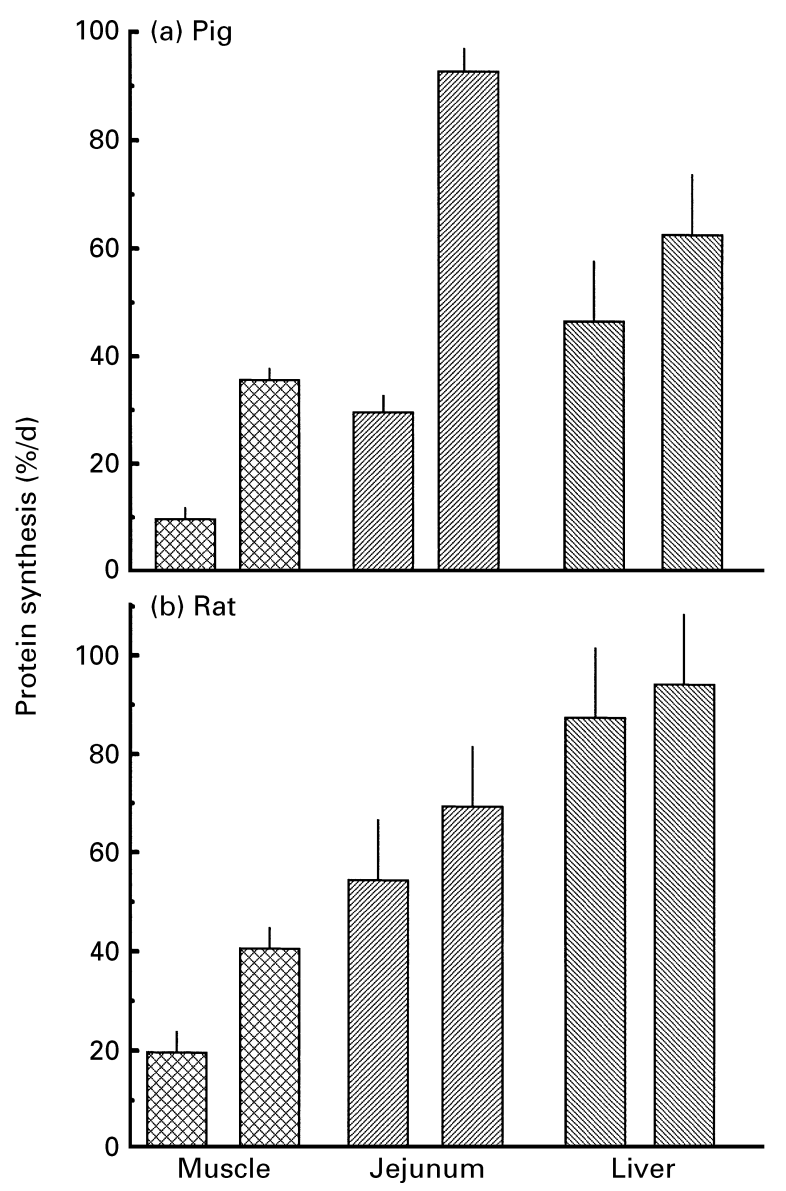

Fig. 4. Changes in tissue protein synthesis of (a) pigs and (b) rats over the first day of postnatal life. Pig data from Burrin et al. (1995); rat data from Goldspink et al. (1984), Lewis et al. (1984), Davis et al. (1991) and Burrin et al. (1992). Values are means with SE represented by vertical bars.

concentrations of a wide variety of potential growthregulatory molecules, and studies in piglets (Burrin et al. 1995, 1997a; Fig. 5) have shown that some, but not all, tissues increase their rate of protein synthesis to a greater extent when the animal receives colostrum than when it receives an equal amount of nutrients provided in a formula.

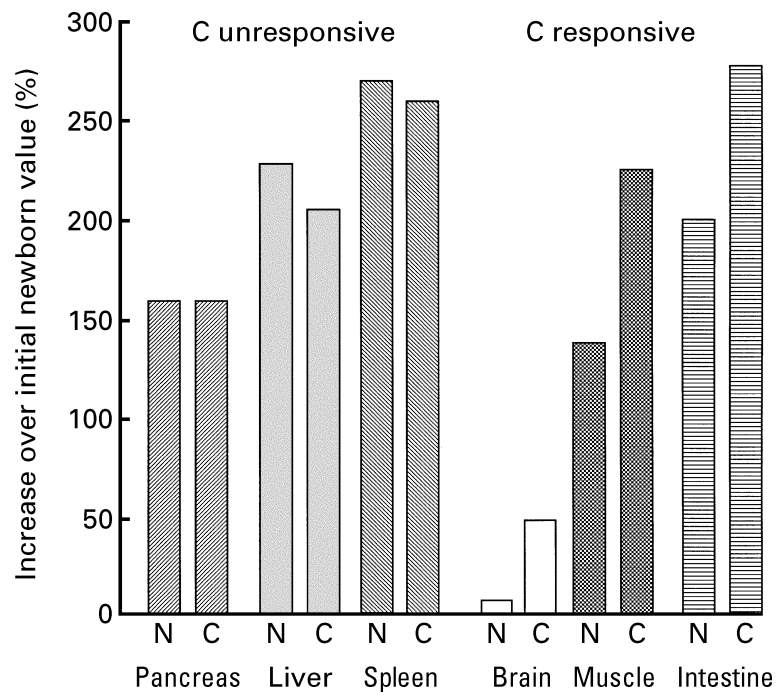

Fig. 5. Nutrient (N)- and colostrum(C)-stimulated increases in tissue protein synthesis in newborn pigs. Values are means and 1SD represented by vertical bars. Data taken from Burrin et al. (1995, 1997a).

In some respects the stimulatory effect of colostrum on small intestinal protein synthesis is to be expected, because this tissue will be exposed directly to the hormones and peptide growth factors in colostrum. However, these data also show that peripheral tissues, notably the skeletal musculature (Burrin et al. 1995) and the brain (Burrin et al. $1997 a$ ), are specifically responsive to colostrum. Moreover, in skeletal muscle the response to colostrum appears to be confined to the synthesis of myofibrillar proteins (Fiorotto et al. 1995). Although such experiments have not been performed in other species, it is noteworthy that in the newborn rat the synthesis of myofibrillar protein is higher than that of the sarcoplasmic proteins. Unfortunately, at this stage the mechanism that mediates these apparently specific effects of colostrum is not known, although it appears that neither insulin nor insulin-like growth factor 1 are involved directly. Indeed, given the response in the central nervous system, it is tempting to speculate that the colostrum stimulation of protein synthesis is not a response to a soluble growth factor or hormone absorbed by the neonate, but that 
the ingestion of colostrum generates regulatory (perhaps neural) signals from the small intestine.

The general fall in whole-body protein synthesis that occurs over the sucking period also conceals quite marked differences in individual tissues. Thus, as we show in Fig. 6, in the rat during the first 3 weeks of life the fractional rate of protein synthesis in the small intestine rises, the rate of protein synthesis in the liver remains essentially constant, and it is only in skeletal muscle and the skin (data not shown), which have particularly high rates of protein synthesis at $1 \mathrm{~d}$ after birth, that the fractional rate of protein synthesis falls between birth and weaning. In this regard, it is interesting to note that, although these changes appear to be largely a function of a reduction in the concentration of ribosomes, there are indications, in the rat at least, that as the animal approaches weaning the translational activity of the ribosomes increases. Essentially identical data have been found in the pig (Davis et al. 1996), and it seems likely to us that similar changes occur in the newborn of other species.

The observations summarized in Figs. 5 and 6 were all made in animals that had not been deprived of food before the measurement of protein synthesis. This observation is critical, because quite clearly growth only occurs as a result of the activation of protein anabolism following the

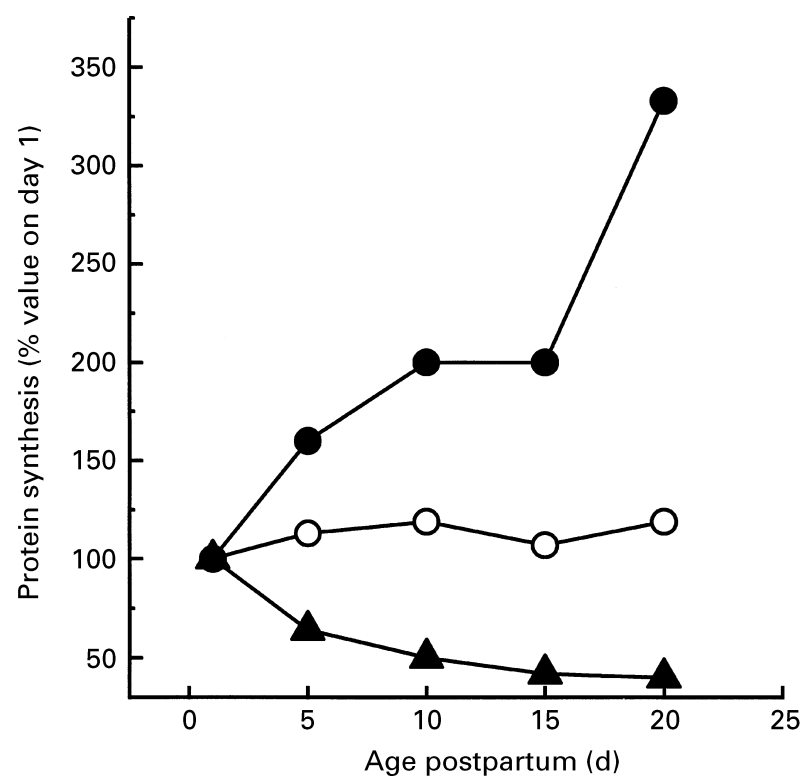

Fig. 6. Changes with age in the fractional rate of synthesis in

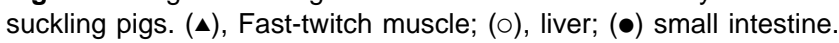
(Data for fed animals from Davis et al. 1991 and Burrin et al. 1991, 1992.) ingestion of nutrients. In fact, it has been shown, in both rats and pigs, that in those tissues that exhibit a marked fall in protein synthesis as development proceeds, much of the difference relates to the response to nutrient intake itself. This factor, we believe, is closely related to another phenomenon associated with growth during the immediate postnatal period.

In the discussion of the utilization of milk amino acids, we highlighted the fact that over the whole of the preweaning period the efficiency with which milk amino acids are deposited in body protein is very high. However, the data that we used to support this statement were deliberately assembled for the whole sucking period, and when we examine the efficiency of milk amino acid utilization across the sucking period itself it is clear that the efficiency of amino acid utilization also falls. Critically, this decrease in efficiency is not simply a reflection of the interaction between protein intake, deposition and maintenance requirements, because when the estimated maintenance amino acid needs are taken into account the incremental efficiency of protein utilization in pigs, sheep and rats falls from between 79 and $85 \%$ during the first week of life to between 52 and $68 \%$ by the fourth week.

The fact that the efficiency of amino acid utilization for protein deposition falls in parallel with the fed rate of wholebody protein synthesis, suggests to us that the efficiency of amino acid utilization is linked in some way to the degree to which a given meal can stimulate protein anabolism. For skeletal muscle, but critically not for secretory tissues such as the intestine and liver, this link appears to be present. Data from both rats (Table 7) and pigs (Davis et al. 1996) show that the increase in the fractional rate of muscle protein synthesis associated with feeding falls progressively from birth to weaning. Of particular importance is the observation that the increase in total muscle protein synthesis per unit protein intake also falls; i.e. postnatal development is associated with a progressively lower protein synthetic response to the ingestion of a given quantity of protein. This finding suggests that as the animal approaches weaning the protein taken in a given meal becomes progressively greater than the magnitude of the anabolic response that the animal is capable of mounting. The consequence is that increasingly larger quantities of dietary amino acids are catabolized shortly after their absorption.

These observations pose the question of which regulatory factors are responsible not only for the stimulation of protein synthesis by feeding, but also for the apparent fall in this stimulation as development proceeds. In order to gain some

Table 7. The relationship between weight-specific protein intake and the effect of feeding on protein synthesis in the plantaris muscle of sucking and weaned rats (Recalculated from Davis et al. 1989, 1991)

\begin{tabular}{|c|c|c|c|c|c|c|c|}
\hline \multirow[b]{3}{*}{ Age (d) } & \multirow[b]{3}{*}{ Protein intake ( $\mathrm{g} / \mathrm{kg}$ per $\mathrm{d})$} & \multicolumn{4}{|c|}{ Protein synthesis } & & \\
\hline & & \multicolumn{2}{|c|}{ Fractional rate $(\%$ per $d)$} & \multicolumn{2}{|c|}{ Absolute rate $(\mathrm{mg} / \mathrm{d})$} & \multicolumn{2}{|c|}{ Change in protein synthesis (mg) } \\
\hline & & Fed & Fasted & Fed & Fasted & per kg body wt & per g protein intake \\
\hline 5 & 33 & 33 & 16 & $0 \cdot 11$ & 0.05 & $6 \cdot 0$ & $0 \cdot 181$ \\
\hline 10 & 30 & 24 & 16 & 0.23 & 0.15 & 3.83 & 0.127 \\
\hline 16 & 28 & 25 & 20 & 0.71 & 0.57 & $4 \cdot 11$ & 0.146 \\
\hline 21 & 22 & 22 & 20 & $1 \cdot 32$ & $1 \cdot 21$ & $2 \cdot 0$ & 0.083 \\
\hline
\end{tabular}


more insights into this important question of growth regulation, Davis, Wray-Cahen and Beckett (see WrayCahen et al. 1997) have developed an insulin-glucoseamino acid clamp technique, and have used this technique with 7-d- and 26-d-old pigs to attempt to answer two key questions:

1. under conditions of constant substrate concentrations does insulin stimulate tissue protein synthesis to the same degree as feeding?

2. are changes in the response of tissue protein synthesis to insulin the primary factor responsible for the fall in the metabolic response to feed intake?

In their first experiments the influence of insulin on whole-body amino acid utilization was investigated. The results of this experiment (Fig. 7) revealed a number of interesting observations. First, at insulin concentrations (approximately $30 \mu \mathrm{U} / \mathrm{ml}$ ) that were characteristic of the fed state whole-body amino acid disposal approached an asymptotic value which approximated to $65 \%$ of the amino acid intake of the sow-fed piglet. Second, the amino acid utilization of the younger pigs was very sensitive to insulin, with a measurable effect occurring at insulin concentrations below $10 \mu \mathrm{U} / \mathrm{ml}$. Third, increasing age was associated with the appearance of a distinct threshold (approximately $20 \mu \mathrm{U} / \mathrm{ml}$ ) below which there appeared to be no effect of insulin on amino acid utilization. Finally, the insulin concentration for half maximal stimulation of amino acid utilization shifted from $18 \mu \mathrm{U} / \mathrm{ml}$ in the 7-d-old pigs to $45 \mu \mathrm{U} / \mathrm{ml}$ in the 26-d-old animals, and the maximum response was substantially lower in the older group. Taken together these data imply that on a whole-body basis the fall

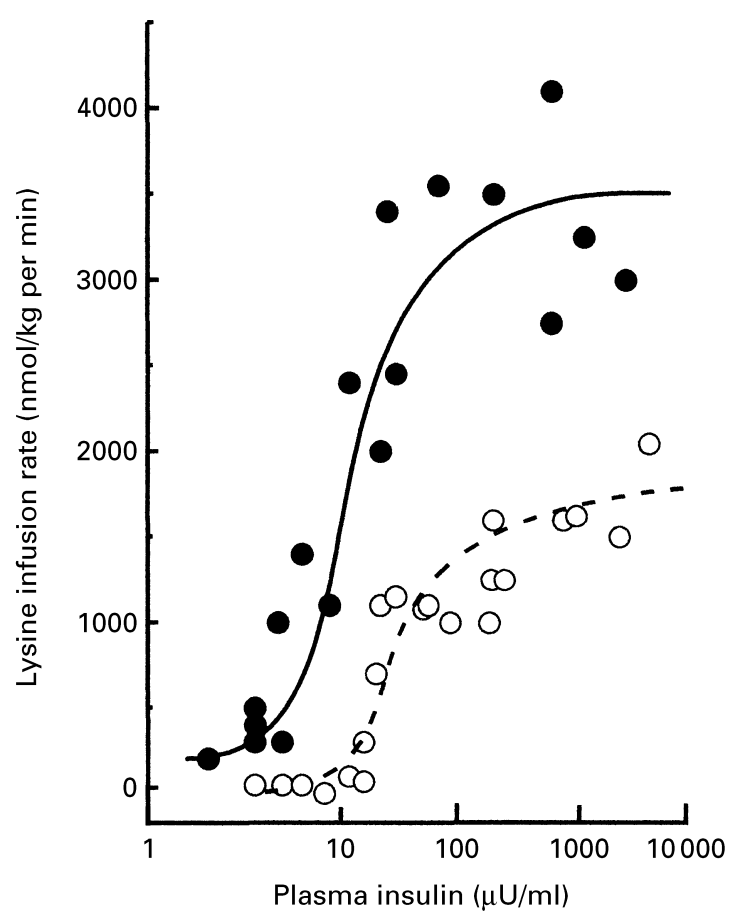

Fig. 7. The effect of insulin on amino acid utilization in 7- (•) and 26 (०)-d-old pigs. (Replotted from Wray-Cahen et al. 1997.) in the efficiency of protein utilization is reflected in changes in both the sensitivity and the responsiveness of protein deposition to insulin.

This experiment left unanswered the question of whether the influence of insulin on whole-body amino acid disposal was due to a stimulation of tissue protein synthesis. In fact, when tissue protein synthesis was measured at the end of a $6 \mathrm{~h}$ hyperinsulinaemic-euaminoacidaemic clamp (WrayCahen et al. 1998) it became clear that once again wholebody responses had concealed important differences among the tissues (Table 8). Thus, as had been observed by Garlick et al. (1983) in rats, insulin, within the normal range, was capable of fully stimulating muscle protein synthesis to the fed value. However, protein synthesis in the liver, and the intestine (data not shown), was completely unresponsive to insulin. In addition to these tissue differences, Davis' studies (Wray-Cahen et al. 1998) on protein synthesis demonstrated two other important phenomena. First, the responsiveness of muscle protein synthesis to insulin fell with age. Second, insulin-stimulated muscle protein synthesis reached a maximum at insulin levels (approximately $10 \mu \mathrm{U} / \mathrm{ml}$ ) well below those required to maximize whole-body amino acid disposal. Given that insulin lowered the rate of whole-body degradation (at least as estimated from leucine kinetics), this result implies that the efficient disposal of dietary amino acids requires both a stimulation of protein synthesis and a reduction in protein degradation.

The interaction between amino acids and insulin in regulating tissue protein synthesis in sucking animals is currently under investigation. Table 8 shows data from 7 -d-old pigs. These results show that in skeletal muscle both insulin and amino acids can stimulate protein synthesis independently of one another, but that in liver only amino acids are capable of stimulating protein synthesis. Finally, preliminary data suggest that the responsiveness of muscle protein synthesis to amino acids is also much lower in 26-d-old pigs compared with 7-d-old pigs. The picture that emerges, therefore, is that the fall in protein synthesis, and the associated fall in the efficiency of amino acid utilization, appear to be related to the capacity of the tissues to synthesize protein and the magnitude of the response to any anabolic stimulator. This pattern undoubtedly reflects a fall in the ribosome concentration, and studies are under way to investigate whether the ancillary translation factors alter in activity with age.

Table 8. Effect of feeding, insulin and amino acids on the fractional rate of tissue protein synthesis $(\% / d)$ in 7-d-old pigs. Data of Davis et al. 1996 and TA Davis, D Wray-Cahen and H Nguyen, unpublished results

\begin{tabular}{|c|c|c|c|c|c|c|}
\hline \multirow[b]{2}{*}{ Tissue } & \multicolumn{5}{|c|}{ Condition } & \multirow[b]{2}{*}{ Pooled SD } \\
\hline & Fast & $\begin{array}{c}\text { Insulin } \\
(30 \mu \bigcup / m l)\end{array}$ & $\begin{array}{c}\text { Amino } \\
\text { acids }(2 \times \\
\text { fasting })\end{array}$ & $\begin{array}{c}\text { Insulin + } \\
\text { amino } \\
\text { acids }\end{array}$ & Fed & \\
\hline Muscle & 11.9 & $19 \cdot 3^{*}$ & $19.9^{*}$ & $21 \cdot 7^{\star}$ & $23.7^{*}$ & 2.8 \\
\hline Liver & 64 & 67 & $78^{*}$ & $81^{*}$ & $87^{*}$ & 7 \\
\hline
\end{tabular}

*Values were significantly different from the fasting value: $P<0.05$ 


\section{Conclusion}

Over the last 20 years, large strides have been made in understanding growth and metabolic regulation in the neonate. Nevertheless, a number of critically-important questions remain. Thus, although it is clear that the neonate is capable of carrying out extensive amino acid interconversions, the pathways and the regulatory mechanisms remain poorly characterized. Similarly, although the changes in protein turnover that accompany the transition from birth to weaning are clearly regulated, and presumably genetically and developmentally programmed, the underlying regulatory factors and the mechanisms by which they exert their effects are areas of substantial ignorance. This situation is regrettable, because the nutritional experiences during the neonatal period are of crucial importance to the long-term health of the individual.

Finally, we believe that it is important to emphasize that the neonate presents a potentially powerful tool for understanding broader aspects of the regulation of tissue function and growth regulation. Thus, understanding the protein and amino acid metabolism of the neonate might well enhance our knowledge of the adult, and hence contribute important information of relevance to the nutritional amelioration of metabolic diseases associated with maturity and old age.

\section{Acknowledgements}

This work is a publication of the USDA/ARS Children's Nutrition Research Center, Department of Pediatrics, Baylor College of Medicine and Texas Children's Hospital, Houston, TX, USA. The work was supported in part by federal funds from the US Department of Agriculture Agricultural Research Service, Cooperative Agreement no. 58-6258-6001, by the National Institutes of Health (R01 HD33920 and RO1-HD35679) and by the International Glutamate Technical Committee. JB van Goudoever was supported by the Royal Dutch Academy of Science, Nutricia Research Foundation and the Sophia Foundation for Scientific Research. The contents of this publication do not necessarily reflect the views or policies of the US Department of Agriculture, nor does mention of trade names, commercial products, or organizations imply endorsement by the US Government. We are indebted to Dr S Leigh for information on the early growth of the great apes, and to Drs AW Bell and P Greenwood for providing data on the nutrition and growth of the sucking lamb. Finally, we thank L Loddeke for her careful editing of this paper.

\section{References}

Anderson LL, Hard DL, Trenkle AH \& Cho SJ (1999) Long-term growth after hypophyseal stalk transection and hypophysectomy of beef calves. Endocrinology 140, 2405-2414.

Attaix D, Aurousseau E, Manghebati A \& Arnal M (1988) Contribution of liver, skin and skeletal muscle to whole-body protein synthesis in the young lamb. British Journal of Nutrition 60, 77-84.

Beaufrere B, Fournier V, Salle B \& Putet G (1992) Leucine kinetics in fed low-birth-weight infants: importance of splanchnic tissues. American Journal of Physiology 263, E214-E220.
Berthold HK, Crain PF, Gouni I, Reeds PJ \& Klein PD (1995) Evidence for incorporation of intact dietary pyrimidine (but not purine) nucleosides into RNA. Proceedings of the National Academy of Sciences USA 92, 10123-10127.

Blachier F, M'Rabet-Touil H, Posho L, Darcy-Vrillon B \& Duee PH (1993) Intestinal arginine metabolism during development. Evidence for de novo synthesis of L-arginine in newborn pig enterocytes. European Journal of Biochemistry 216, 109-117.

Boza JJ, Jahoor F \& Reeds PJ (1996) Ribonucleic acid nucleotides in maternal and fetal tissues derive almost exclusively from synthesis de novo in pregnant mice. Journal of Nutrition 126, 1749-1758.

Burrin DG, Davis TA, Ebner S, Schoknecht PA, Fiorotto ML \& Reeds PJ (1997a) Colostrum enhances the nutritional stimulation of vital organ protein synthesis in neonatal pigs. Journal of Nutrition 127, 1284-1289.

Burrin DG, Davis TA, Ebner S, Schoknecht PA, Fiorotto ML, Reeds PJ \& McAvoy S (1995) Nutrient-independent and nutrient-dependent factors stimulate protein synthesis in colostrum-fed newborn pigs. Pediatric Research 37, 593-599.

Burrin DG, Davis TA, Fiorotto ML \& Reeds PJ (1991) Stage of development and fasting affect protein synthetic activity in the gastrointestinal tissues of suckling rats. Journal of Nutrition 121, 1099-1108.

Burrin DG, Davis TA, Fiorotto ML \& Reeds PJ (1992) Hepatic protein synthesis in suckling rats: effects of stage of development and fasting. Pediatric Research 31, 247-252.

Burrin DG, Davis TA, Fiorotto ML \& Reeds PJ (1997b) Role of milk-borne vs endogenous insulin-like growth factor in neonatal growth. Journal of Animal Science 75, 2739-2743.

Darmaun D, Roig JC, Auestad N, Sager BK \& Neu J (1997) Glutamine metabolism in very low birth weight infants. Pediatric Research 41, 391-396.

Davis TA, Burrin DG, Fiorotto ML \& Nguyen HV (1996) Protein synthesis in skeletal muscle and jejunum is more responsive to feeding in 7- than in 26-day-old pigs. American Journal of Physiology 270, E802-E809.

Davis TA, Fiorotto ML, Nguyen HV, Burrin DG \& Reeds PJ (1991) Response of muscle protein synthesis to fasting in suckling and weaned rats. American Journal of Physiology 261, R1373-R1380.

Davis TA, Fiorotto ML, Nguyen HV \& Reeds PJ (1989) Protein turnover in skeletal muscle of suckling rats. American Journal of Physiology 257, R1141-R1146.

Davis TA, Fiorotto ML \& Reeds PJ (1993) Amino acid compositions of body and milk protein change during the suckling period in rats. Journal of Nutrition 123, 947-956.

Davis TA, Nguyen HV, Costa DP \& Reeds PJ (1995) Amino acid composition of pinniped milk. Comparative Biochemistry and Physiology 110B, 633-639.

Davis TA, Nguyen HV, Garcia-Bravo R, Fiorotto ML, Jackson EM, Lewis DS, Lee DR \& Reeds PJ (1994) Amino acid composition of human milk is not unique. Journal of Nutrition 124, $1126-1132$.

de Benoist B, Abdulrazzak Y, Brooke OG, Halliday D \& Millward DJ (1984) The measurement of whole body protein turnover in the preterm infant with intragastric infusion of L-[1-13C]leucine and sampling of the urinary leucine pool. Clinical Science 66, $155-164$.

Denne SC, Karn CA \& Liechty EA (1992) Leucine kinetics after a brief fast and in response to feeding in premature infants. American Journal of Clinical Nutrition 56, 899-904.

Denne SC, Karn CA, Liu YM, Leitch CA \& Liechty EA (1994) Effect of enteral versus parenteral feeding on leucine kinetics and fuel utilization in premature newborns. Pediatric Research 36, 429-435. 
Denne SC, Karn CA, Wang J \& Liechty EA (1995) Effect of intravenous glucose and lipid on proteolysis and glucose production in normal newborns. American Journal of Physiology 269, E361-E367.

Denne SC, Rossi EM \& Kalhan SC (1991) Leucine kinetics during feeding in normal newborns. Pediatric Research 30, 23-27.

Dewey KG, Beaton G, Fjeld C, Lonnerdal B \& Reeds P (1996) Protein requirements of infants and children. European Journal of Clinical Nutrition 50, Suppl 1., S119-S147.

Dourmad JY, Noblet J \& Etienne M (1998) Effect of protein and lysine supply on performance, nitrogen balance, and body composition changes of sows during lactation. Journal of Animal Science 76, 542-550.

Fiorotto ML, Burrin DG, Perez M \& Reeds PJ (1991) Intake and use of milk nutrients by rat pups suckled in small, medium, or large litters. American Journal of Physiology 260, R1104-R1113.

Fiorotto ML, Davis TA, Czerwinski SM, Reeds PJ \& Burrin DG (1995) Colostrum stimulates myofibrillar protein synthesis in newborn pigs. FASEB Journal 9, A580.

Francis GL, Upton FM, Ballard FJ, McNeil KA \& Wallace JC (1988) Insulin like growth factors 1 and 2 in bovine colostrum. Biochemical Journal 251, 95-103.

Fuller MF, McWilliam R, Wang TC \& Giles LR (1989) The optimum dietary amino acid pattern for growing pigs. 2 . Requirements for maintenance and for tissue protein accretion. British Journal of Nutrition 62, 255-267.

Garlick PJ, Fern M, Preedy VR (1983) The effect of insulin infusion and food intake on muscle protein synthesis in postabsorptive rats. Biochemical Journal 210, 669-676.

Goldspink DF \& Kelly FJ (1984) Protein turnover and growth in the whole body, liver and kidney of the rat from the foetus to senility. Biochemical Journal 217, 507-516.

Goldspink DF, Lewis SE \& Kelly FJ (1984) Protein synthesis during the developmental growth of the small and large intestine of the rat. Biochemical Journal 217, 527-534.

Greenwood PL, Hunt AS, Hermanson JW \& Bell AW (1998) Effects of birth weight and postnatal nutrition on neonatal sheep: I. Body growth and composition, and some aspects of energetic efficiency. Journal of Animal Science 76, 2354-2367.

Harris PM, Skene PA, Buchan V, Milne E, Calder AG, Anderson SE, Connell A \& Lobley GE (1992) Effect of food intake on hind-limb and whole-body protein metabolism in young growing sheep: chronic studies based on arterio-venous techniques. British Journal of Nutrition 68, 389-407.

Jackson AA, Shaw JC, Barber A \& Golden MH (1981) Nitrogen metabolism in preterm infants fed human donor breast milk: the possible essentiality of glycine. Pediatric Research 15, 1454-1461.

Kandil H, Darwish O, Hammad S, Zagloul N, Halliday D \& Millward J (1991) Nitrogen balance and protein turnover during the growth failure in newly born low-birth-weight infants. American Journal of Clinical Nutrition 53, 1411-1417.

Klagsbrun M (1978) Human milk stimulates DNA synthesis and cellular proliferation in cultured fibroblasts. Proceedings of the National Academy of Sciences USA 75, 5057-5061.

Lewis SE, Kelly FJ \& Goldspink DF (1984) Pre- and post-natal growth and protein turnover in smooth muscle, heart and slowand fast-twitch skeletal muscles of the rat. Biochemical Journal 217, 517-526.

McMeekan CP (1940) Growth and development of the pig, with special reference to carcass quality characteristics. Journal of Agricultural Science, Cambridge 30, 276-336.

MacRae JC, Skene PA, Connell A, Buchan V \& Lobley GE (1988) The action of the beta-agonist clenbuterol on protein and energy metabolism in fattening wether lambs. British Journal of Nutrition 59, 457-465.
Macy IG (1949) Composition of human colostrum and milk. American Journal of Diseases of Childhood 78, 589-603.

Mahan DC \& Shields RG Jr (1998) Essential and nonessential amino acid composition of pigs from birth to 145 kilograms of body weight, and comparison to other studies. Journal of Animal Science 76, 513-521.

Miller RG, Keshen TH, Jahoor F, Shew SB \& Jaksic T (1996) Compartmentation of endogenously synthesized amino acids in neonates. Journal of Surgical Research 63, 199-203.

Motil KJ, Harmon WE \& Grupe WE (1980) Complications of essential amino acid hyperalimentation in children with acute renal failure. Journal of Parenteral and Enteral Nutrition 4, 32-35.

Neame KB \& Wiseman G (1957) The transamination of glutamic and aspartic acids during absorption by the small intestine of the dog in vivo. Journal of Physiology 135, 442-450.

Newburg DS (1997) Do the binding properties of oligosaccharides in milk protect human infants from gastrointestinal bacteria? Journal of Nutrition 127, 980S-984S.

Odle J, Zijlstra RT \& Donovan SM (1996) Intestinal effects of milkborne growth factors in neonates of agricultural importance. Journal of Animal Science 74, 2509-2522.

Patureau-Mirand P, Mosoni L, Levieux D, Attaix D, Bayle G \& Bonnet Y (1990) Effect of colostrum feeding on protein metabolism in the small intestine of newborn lambs. Biology of the Neonate 57, 30-36.

Pell JM, Caldarone EM \& Bergman EN (1986) Leucine and $\alpha$-ketoisocaproate metabolism and interconversion in fed and fasted sheep. Metabolism 35, 1005-1016.

Perez JF \& Reeds PJ (1998) A novel stable isotopic approach enables the simultaneous determination of protein and RNA synthesis in vivo. Journal of Nutrition 128, 1562-1569.

Rassin DK, Sturman JA \& Guall GE (1978) Taurine and other free amino acids in milk of man and other mammals. Early Human Development 2, 1-13.

Reeds PJ \& Beckett P (1996) Protein and amino acids. In Present Knowledge in Nutrition, 7th ed., pp. 67-86 [E Zeigler and J Filer, editors]. Washington, DC: ILSI Press.

Reeds PJ, Burrin DG, Jahoor F, Wykes L, Henry J \& Frazer EM (1996) Enteral glutamate is almost completely metabolized in first pass by the Gl tract of infant pigs. American Journal of Physiology 270, E413-E418.

Reeds PJ, Cadenhead A, Fuller MF, Lobley GE \& McDonald JD (1980) Protein turnover in growing pigs. Effects of age and food intake. British Journal of Nutrition 43, 445-455.

Romain N, Dandrifosse G, Jeusette F \& Forget P (1992) Polyamine concentration in rat milk and food, human milk and infant formulas. Pediatric Research 32, 58-63.

Smith RJ \& Leigh SR (1998) Sexual dimorphism in primate neonatal body mass. Journal of Human Development 34, 173-201.

Snell K \& Walker DG (1974) Regulation of hepatic L-serine dehydratase and L-serine-pyruvate aminotransferase in the developing neonatal rat. Biochemical Journal 144, 519-531.

Stoll B, Burrin DG, Henry J, Yu H, Jahoor F \& Reeds PJ (1999) Substrate oxidation by the portal drained viscera of fed piglets. American Journal of Physiology 277, 168-175.

Sugawara M, Nakano T, Idota T \& Nakajima I (1995) Profile of nucleotides and nucleosides of human milk. Journal of Nutritional Science and Vitaminology 41, 409-418.

Uauy R, Quan R \& Gil A (1994) A role of nucleotides in intestinal development and repair: implications for infant nutrition. Journal of Nutrition 124, 1436S-1441S.

Van Goudoever JB, Sulkers EJ, Halliday D, Degenhart HJ, Carnielli VP, Wattimena JL \& Sauer PJ (1995) Whole-body protein turnover in preterm appropriate for gestational age and small for gestational age infants: comparison of $[15 \mathrm{~N}]$ glycine 
and [1-(13)C]leucine administered simultaneously. Pediatric Research 37, 381-388.

Wakabayashi YE, Yamada T, Yoshida T \& Takahashi N (1995) Effect of intestinal resection and arginine-free diet on rat physiology. American Journal of Physiology 269, G313-G318.

Windmueller H \& Spaeth AE (1980) Respiratory fuels and nitrogen metabolism in vivo in small intestine of fed rats. Quantitative importance of glutamine, glutamate, and aspartate. Journal of Biological Chemistry 255, 107-112.

Wray-Cahen D, Beckett PR, Nguyen HV \& Davis TA (1997) Insulin-stimulated amino acid utilization during glucose and amino acid clamps decreases with development. American Journal of Physiology 273, E305-E314.
Wray-Cahen D, Nguyen HV, Burrin DG, Beckett PR, Fiorotto ML, Reeds PJ, Wester TJ \& Davis TA (1998) Response of skeletal muscle protein synthesis to insulin in suckling pigs decreases with development. American Journal of Physiology 275, E602-E609.

Wu G, Davis PK, Flynn NE, Knabe DA \& Davidson JT (1997) Endogenous synthesis of arginine plays an important role in maintaining arginine homeostasis in post weaning growing pigs. Journal of Nutrition 127, 2342-2349.

Wu G \& Knabe DA (1995) Arginine synthesis in enterocytes of neonatal pigs. American Journal of Physiology 269, R621-R629.

Wu G, Ott TL, Knabe DA \& Bazer FW (1999) Amino acid composition of the fetal pig. Journal of Nutrition 129, 1031-1038. 